\title{
Eviction Policy in Postwar Angola
}

\author{
Jon D. Unruh \\ McGill University
}

\begin{abstract}
Angola's four decades of civil war continue to have a profound effect on the country's recovery and development. While the end to the war in 2002 and the subsequent extraction of natural resources has fueled the country's economic recovery for a minority, for the majority recovery depends less on natural resource extraction than it does on acquiring and maintaining secure access to land and property upon which viable livelihoods can be rebuilt. However the current large scale evictions in urban and peri-urban areas of the country and the resulting acute tenure insecurity is significantly worrying, and is the single most acute land rights, land policy, and political problem in the country. Aspects of the country's constitution and the development of the postwar land law facilitate eviction, and an important opportunity to upgrade postwar informal land rights has been missed. Land and property rights problems have played a significant role in the country's armed conflicts and social problems, and current trends are constructing a difficult future.
\end{abstract}

Keywords: Angola, land rights, urban, peri-urban, rural, evictions, law, policy.

\section{Introduction}

During Angola's war periods (1961 - 1974; 1975 - 1975; 1975 - 2002), forced dislocation and migration to the cities was dramatic. The end to the war in 2002 led to a scramble for land and property involving a variety of competing interests--government, returning displaced rural and urban inhabitants, commercial interests, and migrants to new areas. While the government and the international community shared the goal of having dislocated populations return quickly to areas of origin, this was difficult for many, including troops from the UNITA rebel force, because many were faced with returning to locations that they may have looted or terrorized during the war. In addition many of the dislocated and ex-combatants had left their rural family land as long as 30 years earlier and upon their return discovered that they had been bypassed or excluded from land inheritance practices--with inheritance the primary way to acquire land. While most of the dislocated arrived in urban and peri-urban areas in order to escape the war, migration to these areas is ongoing as people seek economic opportunity (AI 2007; DW 2004) and escape the lack of it in rural areas.

Land expropriation and concentration of land holdings by colonial settlers was one of the primary reasons for the independence war, to the degree that the conflict came to be equated with land rights (Cain forthcoming). As well land rights were one of the primary causes of the subsequent UNITA war. During the country's forty years of armed conflict, mass evictions, land grabbing, large-scale displacement and resettlement were primary features. Presently, forced evictions in Angola have become the most volatile political issue in the country--'explosive' by 
some accounts (Economist 2011)--with violence and heavy handedness by state security forces common. The eviction process has destroyed houses and crops without compensation (Foley 2007). Human Rights Watch notes that such evictions are in many cases carried out contrary to both Angolan and international law (HRW 2007; also Kothari 2006). With rising urban and periurban land values, aggressive large-scale evictions have taken place, and large numbers of people are threatened with eviction. This drives down tenure security for even larger numbers of people. A primary reason for such evictions is to clear land for the construction of commercial buildings and wealthy residential areas. And while there are government and NGO organizations that provide services and advocacy for the urban poor, these are overwhelmed by the enormity of the challenge of protecting the rights of those evicted or threatened with eviction (Robson 2001). Such a challenge includes the eviction and expulsion of approximately 250,000 undocumented Congolese from Angola between 2003 and June 2011 (IRIN 2011).

There are however sharp contrasts between the urban/peri-urban, and rural areas. While there is stiff competition for lands in the urban and peri-urban areas, and these are where most mass evictions take place, rural areas are much less subject to such competition. Rural Angola is land abundant and underutilized due in part to a lack of road infrastructure. The DDR (disarmament, demobilization and reintegration) process after the war in the rural areas was completed without the large-scale surge of land disputes that are common in many postwar scenarios. Nevertheless rural land tenure is insecure, and there is little protection against land grabbing. For example the issue of occupation vs. ownership of former colonial fazendas (commercial farms) and the 'farm blocks' from the independence socialist era is quite problematic. Both arrangements disintegrated at different times in the Angolan wars and the lands were then occupied by smallholders who in many cases claimed them as lineage land. However the fazenda and farm block cadastres to which these lands were attached, along with the colonial land registry, came to be used by the Angolan elite to title rural lands and use them for commercial purposes, speculation, or rent, evicting the smallholder occupants in the process.

\section{The Policy Problem}

Only a small minority of urban and peri-urban inhabitants have what the state considers formal, secure land tenure. The remainder can easily lose any rights they may feel they have, particularly with the new postwar land legislation. The derivation of Angolan laws regarding land and property over time has steadily decreased rights for the poorer urban resident in favor of expansion of rights for the commercial sector and the well off. Current Angolan legislative efforts continue to reflect these priorities. The post-independence constitution stipulated that the state is the owner of all lands that are not explicitly privately held. Article 11 of the Constitution stated that, "all the existing natural resources in the soil and in the subsoil ... are property of the state, who will determine the conditions of its profit and use" (Hodges 2001). The new Angolan constitution continues along the same lines, and makes explicit that all land in the country belongs to the state, as does the current land law (GoA 2004).

A primary problem is that while land is held under customary forms of tenure for the vast majority of the population, in reality only those who have gone through the lengthy, expensive, 
arduous and corruption ridden process of obtaining formal title to 'surface rights' from provincial government have any real legal status. According to the World Bank, Angola is one of the most difficult countries in the world to register and transfer property titles (WB 2006). The Food and Agricultural Organization of the UN has been working with the Angolan government since 1999 in the construction of what is intended to be a participatory and decentralized land management system, with the aim of enhancing food security (Deve 2007). However the progress in deriving this system is exceedingly slow and it still has not been implemented.

The primary policy instrument that should be regularizing land and property rights in the country is the 2004 land law. The law however is beset by problems, and in a number of ways facilitates evictions. Before the end of the war, work on the new land law began in 2001 and it was ultimately passed by parliament in 2004 as the 'Land Law and the Law of Territorial and Urban Management'. The drafting of the new law was guided by a set of Portuguese lawyers who relied on portions of the Portuguese Civil Code for derivation of the law. As a result there was significant misalignment between the new law and the local level realities regarding war-affected land tenure. The new law does not attend to the needs and problems of the Angolan population. The law is significantly weak in a number of ways with regard to smallholder rights, and favors commercial interests. As in the prewar land law, the acknowledgement of customary rights over land has not conferred tenure security nor prevented expropriation (Pacheco 2002). Instead, the new law has increased the state's power to confiscate land for reasons of 'public use' which can then be given to large-scale commercial interests. Particularly problematic for smallholders is the requirement that all landholders must register their land and obtain title within three years of the law's passage, or ownership passes to the state. This was widely viewed as extremely unrealistic given the very low capacity of government, illiteracy among the smallholder population, and the lack of needed formal identification documents (Foley 2007). While the three year period has now passed, the regulations for applying for title have still not been published. Nevertheless, by the middle of 2010 the new law transferred informal land occupation into official 'illegal occupation' in urban and peri-urban areas, meaning that most urban and peri-urban inhabitants fall into this category.

Certainly one of the most significant problems with the law was the hastiness with which it was derived. A draft of the new land legislation was released in July 2002, just a few months after the official end to the war. The role of the Portuguese lawyers in importing significant components of Portuguese land law in the drafting of the new Angolan law certainly facilitated this time frame. This is perhaps the quickest production of new land legislation of any postwar country-and a large reason for its current failure. While the government did invite public consultation on the 2002 draft, with population dislocation, food insecurity, and impoverization still at wartime levels for the vast majority of the population, it is difficult to see how such a call for consultation could be seen as realistic. This was particularly problematic given that the repeated failures of previous peace accords for the country had resulted in a great many dislocatees not believing the war was actually over, and adopting instead a 'wait and see' position. Since the 'consultation' took place prior to the return of dislocatees, it did not facilitate input with regard to how the new law intersected with the land problems that were emerging in urban and rural areas after the war. 
While the current land law does not attend to those threatened with eviction, two other policy instruments do - if only they could be actually implemented. The 'Memorandum of Understanding between the Government of the Republic of Angola and the UNHCR for the Voluntary Repatriation and Reintegration of Angolan Refugees, 1995' is an agreement which states that dislocated Angolans "shall have the right to return to their former places of residence or to any other places of their choice in Angola". And that, "[t]he government shall ensure that returnees have access to land for settlement and use, in accordance with relevant Angolan laws." In addition, the government is obliged to provide assistance in terms of recovery of property, including land. However the Angolan government's compliance with important parts of this agreement after the close of the war in 2002 has been in most cases quite weak. As well the law known as the Norms on Resettlement of Displaced Persons 2001, was intended to facilitate the return and resettlement of IDPs (internally displaced persons) to their home areas, ensure that the resettlement and reintegration process was accomplished in a participatory way, and guarantee IDPs minimum standards of basic land access and social infrastructure. While this legislation was well intentioned in terms of guaranteeing the rights of IDPs and incorporating international best practices, when the mass resettlement of IDPs took place in 2002 and 2003, there existed very little capacity or willingness on the part of the government to implement the law and guarantee the minimum standards that it described (Cain forthcoming).

\section{Opportunity Missed}

The new law has missed a significant opportunity to deal with the country's IDP and urban migrant population in urban and peri-urban areas, and the regularization of property rights elsewhere in the country. Most occupants in urban and peri-urban settlements had purchased their land or had been allocated land by local authorities, and very few occupants had really squatted on lands. Thus most occupants possess informal documents of some kind demonstrating purchase, while others have improvements and long term occupation to support claims, and still others have old documents demonstrating land allocations by government agricultural programs in areas which have subsequently become peri-urban ${ }^{1}$ (Foley 2007). Thus there are a variety of documents that are possessed through forms of occupation, purchase, or recognition of occupation by local customary and local state authorities. However despite the government's endorsement of the international 'good practice' of progressively recognizing existing occupations and forms of evidence of claim so as to upgrade them over time into secure forms of rights $^{2}$, nevertheless the land law stipulates the elimination of all occupancy (usucapiao) rights where use and occupation was solidified over time (GoA 2004). As a result obtaining land in good faith and the possession of different types of land and property documents do not provide protections against eviction.

\footnotetext{
${ }^{1}$ A 2004 study put the proportion of peri-urban land around Luanda at over 80 percent of all urban land (DW 2004). In a number of other post-conflict countries, informal forms of evidence have also taken the form of unofficial papers attesting to locally valid transactions (Andre 2003, Delville 2003). In effect, such 'pieces of paper' are a means of translating existing evidence for claim into legal or quasi-legal arguments (Unruh 2006).

2 The government of Angola supported this approach at the 1996 Istanbul Urban Forum
} 
There is little political space for voicing opinions about land issues (or other problems regarding the state) in Angola, and resentment is mounting. Open discussion and debate is discouraged with threats, intimidation, and action, and protests are responded to in a heavy handed manner. As a result government closes itself off to learning about potential solutions to land and property problems. Instead it prefers a centrally planned approach which draws on very little of the actual reality of land and property in the country, and which the government does not have the capacity to implement, thus creating the space for corruption and illicit expropriation. Given the large role that problematic land issues have had in Angola's wars and social ills, the combination of the eviction trend, facilitating policies, and low capacity, does not bode well for the country's future.

\section{References}

Andre, C., 2003. Custom, contracts and cadastres in north-west Rwanda. In: Benjaminsen, T.A., and Lund, C. (Eds.), Securing Land Rights in Africa, CASS Publishing, London

Amnesty International (AI), (2007) Angola, lives in ruins, forced evictions continue. Amnesty International AFR 12/001/2007.

Cain, A., (forthcoming) Angola: land resources and conflict. In: Unruh, J., and Williams, R., (Eds.), The Indispensable Asset: Land and Post-conflict Peacebuilding, Earthscan, London.

Delville, P. L., 2003. When farmers use 'pieces of paper' to record their land transactions in Francophone rural Africa: insights into the dynamics of institutional innovation. In: Benjaminsen, T.A., and Lund, C., (Eds.) Securing land rights in Africa, CASS Publishing, London.

Deve, F., 2007. Lessons learning in policy assistance, case study Angola. Support to a decentralized land management programme. Food and Agriculture Organization of the UN, Rome.

Development Workshop (DW), 2004. Land and reintegration of ex-combatants in post war Angola. Development Workshop, Luanda.

Economist, 2011. Angola wealth: mine, all mine. The Economist, February 12.

Foley, C., 2007, Land rights in Angola: poverty and plenty. Humanitarian Policy Group Working Paper. Overseas Development Institute, London.

Government of Angola (GoA), 2004, Lei de terras de Angola, Lei 9/04 de 9 de Nov, de 2004, Government of Angola, Luanda

Hodges, A., 2001, Angola: from Afro-Stalinism to petrodiamond capitalism. James Curry and Indiana University Press, Bloomington. 
Human Rights Watch (HRW), 2007, They pushed down the houses: forced evictions and insecure land tenure for Luanda's urban poor. Human Rights Watch no. A1907.

IRIN, 2011, DRC: Angola's `sans papiers' violently deported in latest wave of expulsions, IRIN Humanitarian News and Analysis, UN Office for the Coordination of Humanitarian Affairs , 17 June.

Kothari, M., 2006, Human rights expert expresses serious concern about persistent practice of forced evictions in Angola. UN Office at Geneva, News and Media, 30 March.

Pacheco, F., 2002, The issue of land and agriculture in Angola. FAO January, Food and Agriculture Organization of the UN, Rome.

Robson, P., 2006, What to do when the fighting stops: challenges for post-conflict reconstruction in Angola. Development Workshop Occasional Paper No. 7, Luanda.

Unruh, J., 2006, Land tenure and the 'evidence landscape' in developing countries. Annals of the Association of American Geographers. 96: 754-772.

World Bank (WB), 2006, Doing business report. World Bank, Washington DC 